\title{
Manajemen Sarana Dan Prasarana Di Mi Qurrota A'yun Sleman
}

\author{
Maratul Qiftiyah $^{1}$, Sandriansyah ${ }^{2}$ \\ Pascasarjana UIN Sunan Kalijaga Yogyakarta ${ }^{12}$ \\ maratulqiftiyah@gmail.com ${ }^{1}$, sandriansyahgejora@gmail.com ${ }^{2}$
}

\begin{abstract}
Abstrak
Madrasah akan dapat berkembang jika sarana dan prasarana pendidikan mendukung proses pembelajaran. Tujuan dari penelitian ini adalah untuk menggambarkan manajemen sarana dan prasarana di MI Qurrota A'yun. Penelitian ini adalah penelitian lapangan menggunakan metode deskriptif dengan pendekatan kualitatif. Subjek utama pada penelitian ini yaitu kepala madrasah. Metode pengumpulan data yang digunakan dalam penelitan ini adalah wawancara dan observasi. Teknik yang digunakan untuk analisis data adalah reduksi data, penyajian data, dan penarikan kesimpulan. Berdasarkan hasil penelitian dapat diketahui bahwa manajemen sarana dan prasarana di MI Qurrota A'yun terdapat beberapa tahapan, diantaranya yaitu: 1) perencanaan sarana dan prasarana dengan menganalisis keseluruhan terlebih dahulu, 2) pengadaan sarana dan prasarana, 3) inventarisasi sarana dan prasarana , 4) pemanfaatan atau penggunaan sarana dan prasarana oleh warga madrasah, pendidik, dan semua peserta didik harus dimonitor oleh pihak yang dipilih madrasah, 5) pemeliharaan sarana dan prasarana sangat penting bagi pendidik dan peserta didik sehingga barang yang ada di madrasah tetap di bawah pengawasan dan perawatan mereka.
\end{abstract}

Kata Kunci: Manajemen, Sarana, Prasarana 


\section{PENDAHULUAN}

Sebuah institusi akan dapat berfungsi secukupnya jika ia mempunyai struktur manajemen yang didukung oleh sumber daya manusia (SDM) yang baik, dana atau biaya, sarana dan prasarana. Madrasah merupakan unit pendidikan mesti mempunyai sarana termasuk buku pelajaran, buku perpustakaan, buku pelengkap, alat praktik, alat peraga, perabot, ATK), dan prasarana (tanah, bangunan, perpustakaan, laboratorium, lapangan olahraga) serta dana yang mencakup dana investasi (dana untuk kepentinganan pembelian tanah, mendirikan bangunan, membeli alat pendidikan termasuk buku-buku dan dana operasional).

Kepentingan sarana dan prasarana untuk mendukung proses pendidikan terdapat pada Undang-Undang Republik Indonesia Nomor 20 Tahun 2003 tentang Sistem Pendidikan Nasional, berbunyi: setiap unit pendidikan formal maupun non formal mempersiapkan sarana dan prasarana yang memadai untuk kebutuhan pendidikan sesuai dengan pertumbuhan dan pengem-bangan potensi fisik, kecerdasan intelektual, sosial, emosi, dan kewajiban peserta didik. Misalnya meliputi gedung, tanah, perlengkap-an administrasi dan lainnya yang digunakan pada proses pengajaran dan pembelajaran. Pendidikan yang baik mesti mempunyai pengelolaan yang baik juga, di mana setiap elemen pengelolaan merekat pada setiap aktivitas, aktivitas kerja, apa yang diharapkan dapat dicapai dengan baik.

Ketentuan sarana dan prasarana ditingkat SD/MI setidaknya memliki: ruang kelas, ruang perpustakaan, laboratorium IPA, ruang pimpinan, ruang guru, tempat beribadah, ruang UKS, jamban, gudang, ruang sirkulasi, dan tempat bermain/berolahraga, hal ini terdapat pada Peraturan Menteri Pendidikan Nasional Nomor 24 Tahun 2007 tentang Standar Sarana Prasarana untuk sekolah/madrasah. Manajemen madrasah dapat efektif dan efisien jika didukung oleh sumber daya manusia (SDM) yang profesional dalam mengoperasikan madrasah, kurikulum yang selaras dengan perkembangan dan karakter peserta didik, kemampuan serta komitmen (tanggungjawab pada tugas) tenaga kependidikan yang cekatan, dan semua didukung oleh sarana-prasarana yang mencukupi untuk mendukung aktivitas pengajaran dan pembelajaran, dana yang mencukupi untuk membayar staf madrasah, dan partisipasi masyarakat yang tinggi. Sekiranya salah satu di atas tidak berfungsi seperti yang diharapkan, maka efektivitas dan efisiensi manajemen madrasah tidak 
akan optimal. Oleh itu, perlu ada keseimbangan antara komponen-komponen di atas. Untuk dapat mencapai keseimbangan ini, pengelola dikehendaki untuk memahami prinsip-prinsip manaje-men sarana prasarana madrasah dalam mencapai tujuan pendidikan tertentu.

Mohamad Mustari (2015: 120) mengemukakan bahwa manajemen sarana dan prasarana merupakan proses kerja sama menggunakan semua sarana dan prasarana secara efektif dan efisien. Sarana dan prasarana juga sangat penting dalam mendukung kelan-caran atau kemudahan belajar, yang berkaitan dengan pendidikan membutuhkan sarana dan prasarana serta penggunaan intensitas dan kreativitas pendidik dan peserta didik dalam aktivitas pembelajaran.

Suharsimi Arikunto dan Lia Yuliana (2008: 273) mengemukakan sarana pendidikan merupakan seluruh fasilitas yang dibutuhkan pada proses pembelajaran baik yang bergerak maupun tidak bergerak sehingga pencapaian pendidikan dapat dilakukan dengan lancar, sistematis, efektif dan efisien. Ibrahim Bafadal (2003: 1) mengatakan bahwa proses pendidikan membutuhkan fasilitas, akan tetapi semua fasilitas harus disediakan sebagaimana kebutuhan yang diperlukan. Sekiranya semua fasilitas sudah tersedia mestilah digunakan dan dirawat dengan benar. Aktivitas manajemen diantaranya yaitu: perencanaan, pengadaan, pengawas-an, penyimpanan, invent-tarisasi, dan penghapusan serta penataan.

MI Qurrota A'yun merupakan institusi pendidikan swasta yang berlokasi di Wedomartani, Ngemplak, Sleman. Madrasah ini sudah boleh dikatakan baik dari segi sarana dan prasarana yang dimiliki. Ini dapat dilihat melalui fasilitas yang terdapat dalam lingkungan madrasah. Mulai dari ruang kelas, ruang pendidik, UKS, jamban, gudang, tempat beribadah, dan sarana prasarana lainnya. Berkaitan dengan kelengkapan sarana dan prasarana pendidikan yang ada di MI Qurrota A'yun, untuk berfungsi dengan baik maka diperlukan manajemen sarana dan prasarana pendidikan. Dengan adanya manajemen sarana dan prasarana pendidikan, maka madrasah akan mampu mengelola sarana dan prasarana pendidikan dengan cara yang lebih konseptual dan terarah. 


\section{METODE PENELITIAN}

Penelitian ini adalah peneltian lapangan menggunakan metode kualitatif dengan pendekatan deskriptif (Sugiyono 2013: 9). Metode ini memberi penekanan kepada gambaran tentang apa yang ada dan selaras dengan realitas terhadap proses manajemen sarana dan parasarana. Penelitian ini dilakukan di MI Qurrota A'yun, desa Wedomartani, kecamatan Ngemplak, kabupaten Sleman.

Subjek utama dalam penelitian ini adalah kepala madrasah. Metode pengumpulan data yang digunakan dalam penelitan ini adalah wawancara dan observasi. Observasi dapat diartikan sebagai mengamati dan merekam secara sistematis pada fenomena yang diteliti. Selain dengan wawancara peneliti juga memperoleh data dengan mengumpulkan informasi berupa dokumen data-data sarana dan prasarana yang ada di madrasah. Teknik yang digunakan untuk analisis data adalah reduksi data, penyajian data, dan penarikan kesimpulan.

\section{HASIL DAN PEMBAHASAN}

\section{Perencanaan Sarana dan Prasarana}

Direktorat Tenaga Kepen-didikan Departemen Pendidikan Nasional (2007: 6) di dalam bukunya Manajemen Sarana dan Prasarana Pendidikan Persekolahan Berbasis Sekolah menyatakan bahwa perencanaan sarana dan prasarana pendidikan merupakan seluruh proses memperkirakan dengan cermat desain pembelian, pengadaan, rehabilitasi, distribusi atau pembuatan peralatan dan persediaan yang sesuai dengan kebutuhan sekolah. Perencanaan adalah langkah pertama mengelola sarana dan prasarana yang juga merupakan langkah pengadaan.

Menurut Bafadal (2004: 27-29) proses perencanaan sarana dan prasarana pendidikan adalah: (1) Mengakomodasi seluruh usulan untuk pengadaan peralatan sekolah yang diajukan oleh masing-masing unit kerja dan atau inventaris kurangnya peralatan sekolah. (2) Menyiapkan planning untuk kebutuhan perlengkapan sekolah pada masa tertentu, seperti untuk satu triwulan atau satu pengajaran. (3) Mengintegrasikan kebutuhan yang sudah direncanakan dengan peralatan yang sebelumnya tersedia. Pada konteks ini, perencana informasi tahu tentang peralatan yang ada di sekolah. Salah satu caranya yaitu dengan membaca buku inventaris atau buku induk barang. Berdasarkan pedoman ini, rencana untuk kebutuhan peralatan disiapkan, yaitu pendaftaran yang belum tersedia di sekolah. (4) Mengintegrasikan 
rencana kebutuhan dengan dana atau anggaran sekolah yang tersedia. Pada konteks ini, apabila tidak cukup dana yang tersedia untuk memenuhi semua kebutuhan yang diperlukan, maka pilihan semua kebutuhan peralatan yang diplanningkan dengan memperhatikan kepentingan dari setiap peralatan yang dibutuhkan. Semua perlengkapan yang mendesak didaftarkan dan diprioritaskan untuk pengadaan. (5) mengintegrasikan planning kebutuhan perlengkapan mendesak dengan dana atau anggaran yang ada, perlu mengadakan seleksi lain dengan cara memperhatikan skala keutamaan. (6) penentuan rencana pengadaan akhir. Perencanaan untuk penyediaan sarana prasarana pendidikan dilakukan berdasarkan analisis kebutuhan dan menentukan skala aktivitas keutamaan yang akan dilakukan dan sesuai dengan dana dan kepentingannya.

Tujuan perencanaan yaitu untuk menghindarikan dari kesalahan ataupun kegagalan yang tidak diinginkan, untuk meningkatkan efektivitas dan efisiensi dalam pelaksanaannya. Manfaat perencana-an diantaranya yaitu dapat membantu menetapkan tujuan, meletakkan fondasi dan mengatur langkah, menghilangkan ketidakpastian, dapat digunakan sebagai petunjuk atau dasar untuk melakukan pengawasan, pengendalian, dan bahkan penilaian sehingga nantinya aktivitas dapat berjalan lancar. Perencanaan yang cermat bisa meminimalkan kemungkinan kesalahan dan juga dapat meningkatkan pengadaan sarana dan prasarana. Maka dari itu, sistem informasi dan koordinasi yang baik diperlukan antara tugas perencana dan petugas pengadaan melalui koordinasi kepemimpinan. Agar terhindar dari kesalahan dalam membeli barang-barang, kepala madrasah harus berkoordinasi dengan pendidik melalui TU untuk meminta sarana yang diusulkan dan diperlukan di kelas.

Berdasarkan hasil temuan penelitian dan teori di atas, terlihat bahwa perencanaan manajemen sarana dan prasarana di MI Qurrota A'yun sudah sesuai dengan ketentuan dalam perencanaan manajemen sarana dan prasarana. Langkah pertama adalah bahwa kepala madrasah bertemu dengan seluruh dewan pendidik dan karyawan, kepala madrasah meminta saran dari dewan pendidik tentang kurangnya fasilitas di kelas. Setiap pendidik harus mengusulkan fasilitas apa yang dibutuhkan, karena pendidik tahu akan kebutuhannya demi kelancaran proses pembelajaran. Usulan dari pendidik kemudian diserahkan kepada kepala madrasah oleh pengelola barang. Selanjutnya kepala madrasah bersama dengan semua tenaga pendidik 
mendiskusikan fasilitas apa yang sangat dibutuhkan untuk dipenuhi. Langkah ini dilakukan karena tidak semua usulan dari pendidik bisa terpenuhi disebabkan terbatasnya dana yang dimiliki oleh madrasah. Di MI Qurrota A'yun dana untuk pengadaan sarana dan prasarana bersumber dari dana bantuan wali murid. Maka dari itu, perbincangan mengenai sarana dan prasarana yang akan dibeli mesti dilakukan supaya selaras dengan kondisi dan dana yang ada sehingga proses pengajaran dan pembelajaran terus dilaksanakan dengan semestinya. Langkah seterusnya selepas menentukan keutamaan pengadaan sarana dan prasarana yang telah disetujui oleh kepala madrasah dan tenaga kependidikan maka surat keputusan hasil rapat dibuat untuk menentukan pengadaan sarana dan prasarana yang ditanda tangani oleh para pendidik yang berpartisipasi dalam pertemuan itu kemudian diketahui oleh kepala madrasah.

\section{Pengadaan Sarana dan Prasarana}

Menurut Syahril (2012: 34) pengadaan sarana dan prasarana pendidikan itu sendiri bermaksud "keseluruhan aktivitas yang dijalankan untuk membentangkan atau menyediakan (dari tidak ada menjadi ada) semua sarana prasarana yang diperlukan untuk pelaksanaan aktivitas sesuai dengan rancangan atau cadangan untuk keperluan yang telah ditetapkan”. Menurut Bafadal (2003: 31), sistem pengadaan sarana dan prasarana di sekolah dapat dilakukan berbagai cara, termasuk: 1) Mengambil dari pemerintah ini adalah bantuan yang diberikan oleh pemerintah ke sekolah. Bantuan ini bersifat terbatas supaya pengelolaan sarana dan prasarana pendidikan di sekolah mesti terus bekerja dengan cara lain; 2) Menyediakan sarana dan prasarana sekolah dengan membeli secara langsung dan melalui pemesanan terlebih dahulu; 3) Meminta sumbangan dari wali murid; 4) Menyediakan perlengkap-an dengan cara menyewa ataupun meminjam ke tempat lain; 5) Memperoleh perlengkapan dengan bertukar barang.

Untuk memenuhi fasilitas di MI Qurrota A'yun, karena mereka tidak menerima bantuan dari pemerintah, madrasah mengadakan pemenuhan fasilitas dengan cara membeli, dalam bentuk barang yang habis pakai seperti spidol, kapur tulis, tinta spidol, penghapus, pensil, pena, kertas, alat kebersihan, peralatan olahraga, dan lainnya. Pada konteks ini madrasah meminta kontribusi dari para wali murid dan dilakukan dengan sangat hati-hati. Karena, tidak semuanya wali murid 
menyetujui dan dapat membantu. Maka dari itu untuk pengadaan sarana dan prasarana madrasah terlebih dahulu mengadakan pertemuan dengan wali peserta didik untuk bersama-sama memerhatikan sarana dan prasarana yang akan dipenuhi demi memenuhi keberlang-sungan pengajaran dan proses pembelajaran.

Kepala madrasah semestinya berani dan tegas dalam membuat keputusan untuk memilih cara pemenuhan sarana dan prasarana dengan cara meminta kontribusi dari wali murid. Disisi lain kepala madrasah juga harus transparan dan berhati-hati untuk menggunakan hibah dari wali murid dengan memberikan laporan tentang penggunaan dana kepada wali murid. Dengan perbaikan ini, diharapkan kebutuhan sarana dan prasarana di MI Qurrota A'yun dapat terpenuhi agar proses pembelajaran dapat berlangsung secara optimal.

\section{Inventarisasi Sarana dan Prasarana}

Inventarisasi sarana dan prasarana adalah aktivitas yang dilaksanakan dalam mencatat semua item di madrasah. Ibrahim Bafadal (2003: 33) menyatakan bahwa dalam pencatatan sarana dan prasarana di sekolah dilakukan pada: a) buku tentang penerimaan barang, mencatat seluruh barang yang diterima oleh sekolah; b) buku asal barang, mencatat dari mana asal barang tersebut (baik dari pembelian, hibah/ hadiah / sumbangan, pertukaran, pinjam / sewa); c) buku golongan inventaris, sebagai buku tambahan dalam melakukan pencatatan barang persediaan sesuai dengan barang yang ditentukan; d) buku induk inventaris, untuk mencatat semua item inventaris milik Negara ataupun yayasan di lingkungan sekolah sesuai dengan tanggal penerimaan pesanan; e) buku non-inventaris, untuk mencatat semua bahan habis pakai diantaranya: spidol, penghapus papan tulis, pensil, tinta, kertas HVS, dan lain-lain; (f) buku inventaris barang, pencatatan barang konsumsi yang masuk/diterima dan barang yang keluar/digunakan dan sisa barang/ stok barang.

Kepala madrasah mendapatkan kesulitan dalam melaksanakan inventarisasi sarana dan prasarana. Maka dari itu kepala MI Qurrota A'yun memilih salah satu pendidik untuk ditugaskan sebagai pengelola sarana dan prasarana madrasah pada masalah inventarisasi. Pendidik yang dipilih yaitu pendidik olah raga. Pada inventarisasi, barang keluar tidak dicatat. Pencatatan dilakukan hanya untuk barang yang masuk. Karena pendidik yang dipilih tidak mempunyai keahlian khusus dalam inventarisasi dan pendidik tesebut juga sibuk mengajar. Kepala madrasah sebaiknya 
mencarikan tenaga honorer untuk mengelola inventarisasi sarana dan prasarana agar proses inventarisasi di madrasah berjalan dengan optimal.

Inventarisasi sarana dan prasarana madrasah untuk barang yang masuk telah dijalankan sepenuhnya dan mencatat penerimaan barang akan tetapi dalam mncatat masih kurang lengkap diantaranya seperti kode barang, nama merek, dan nomor seri dari item tersebut belum tercantum. Madrasah hendaklah menjalankan pencatatan inventaris yang lengkap. Dalam rangka buku inventaris yang akan digunakan sesuai dengan fungsi dan peranannya, pelaksanaannya harus teratur, tertib, dan berkelanjutan, berdasarkan data yang benar, lengkap dan tepat agar dapat memberikan informasi yang tepat. Pencatatan barang-barang keluar belum dilakukan tetapi untuk buku inventaris barang keluar sudah disiapkan. Inventaris barang juga mesti dilakukan supaya kualitas barang yang digunakan dan barang-barang yang rosak pada penggunaannya diketahui sehingga dapat digunakan sebagai acuan untuk pengadaan barang selanjutnya.

Barang yang habis pakai setelah dibeli tidak masuk pada pencatatan buku inventaris. Pencatatan hanya dijalankan apabila barang tersebut diedarkan kepada pendidik dalam format buku diantaranya nomor, nama penerima, tanggal diterima, jenis item yang diterima, bilangan item yang diterima, dan keterangan. Setelah membeli barang harus dicatatkan dalam stok supaya barang-barang yang tersisa setelah barang tersebut didistribusikan kependidik. Dengan catatan persediaan barang, diketahui berapa banyak barang habis pakai yang dibutuhkan oleh masingmasing pendidik.

\section{Pemanfaatan atau Penggunaan Sarana dan Prasarana}

Temuan penelitian tentang pemanfaatan atau penggunaan sarana dan prasarana di MI Qurrota A'yun, yaitu: (1) penggunaan dilakukan oleh administrasi sekolah (2) penggunaan buku pelajaran dilakukan langsung ke pendidik setelah dicatat dalam buku inventaris; (3) penggunaan alat peraga dijalankan secara tidak langsung, yaitu dengan menyimpan-nya terlebih dahulu apabila akan digunakan dan kemudian sesudah digunakan disimpanlah kembali ke tempat asalnya. Penggunaan atau penggunaan fasilitas madrasah seperti buku teks, peralatan olahraga, dan barang habis pakai dilakukan oleh administrasi madrasah. Biasanya administrasi madrasah secara langsung mengirimkan buku-buku ini, peralatan olahraga, dan barang habis 
pakai langsung ke para pendidik. Untuk buku pelajaran, pendidik juga secara langsung mendistribusikan kepada peserta didik.

Pemanfaatan atau pengguna-an untuk peserta didik ini biasanya pendidik memberikan daya tarik sehingga setiap peserta didik memelihara buku-buku dengan cara merawat dan memberi sampul. Pada alat bantu mengajar umumnya tidak diedarkan secara langsung ke pendidik. Ini karena alat bantu pengajaran ini akan digunakan bersama oleh para pendidik, sehingga penggunaannya harus bergiliran. Jika ada pendidik yang akan menggunakan pendidik dapat mengambil alat peraga, setelah penggunaan pendidik semestinya mengembalikan ke tempat asalnya sehingga pendidik lain tidak mengalami kesulitan menemukannya ketika akan menggunakan.

\section{Pemeliharaan Sarana dan Prasarana}

Menurut Mustari (2015: 129) pemeliharaan merupakan aktivitas yang dijalankan untuk memelihara atau mengembalikan peralatan ke kondisi yang dapat diterima. Keadaan peralatan yang senantiasa diterima bertujuan untuk membuat kemudahan sekolah untuk digunakan secara optimum yang mungkin, untuk meningkatkan prestasi dan melanjutkan usia layanan, mengetahui kerusakan atau gejala kerusakan dan untuk menghindari berlakunya kerusakan yang lebih fatal. Cara memelihara sarana dan prasarana diantaranya: (a) pemeliharaan dijalankan setiap hari; (b) selalu tetap bersih, digunakan pada saat dibutuhkan dan disimpan di tempatnya sesudah menggunakan; (c) selalu memeriksa sarana dan prasarana di sekolah untuk memastikan kelayakannya; (d) memeriksa sarana dan prasarana yang rusak dan kemudian memperbaiki, infrastruktur yang tidak bisa diperbaiki akan disimpan. (e) pemeliharaan berkala dilaksana-kan pada bangunan sekolah dan pagar.

Pemeliharaan sarana dan prasarana di MI Qurrota A'yun dilakukan setiap hari sehingga sarana dan prasarana madrasah kebersihan-nya selalu terjaga. Sarana dan prasarana yang dirawat setiap hari diantaranya ruang guru, ruang kelas, halaman, dan jamban. Perawatan harian ini dijalankan dengan cara menyapu, mengepel, dan menyikat. Aktivitas ini dijalankan oleh peserta didik yang dikoordinir oleh pendidik yang piket. Perawatan sarana dan prasarana madrasah juga dilakukan dengan memeriksa keberadaannya, seperti kursi, meja, lemari, dan pintu. Perawatanan ini dijalankan oleh kepala madrasah dengan cara meminta tenaga kependidikan madrasah untuk memeriksa kondisi sarana dan prasarana kemudian melaporkannya 
kepada kepala madrasah. Jika ada sarana dan prasarana yang rusak ditemukan selama pemeriksaan, tenaga kependidikan akan melapor ke kepala sekolah. Jika kerusakannya kecil, kepala madrasah menginstruk-sikan pendidik olahraga dan administrasi untuk memperbaikinya, tetapi apabila rusaknya berat atau parah maka tidak akan diperbaiki karena biaya untuk memperbaiki akan lebih mahal daripada membeli yang baru, selanjutnya akan disimpan di gudang.

Pemeliharaan sarana dan prasarana madrasah juga dijalankan dengan menjaga kebersihan, yang dilakukan pada alat peraga dengan menjaganya tetap bersih dengan menyimpannya di lemari untuk menghindari debu dan digunakan pada saat dibutuhkan, setelah digunakan disimpan di tempat aslinya. Ini dilakukan agar alat peraga tahan lama dan terawat dengan baik. Pemeliharaan juga dijalankan pada bangunan sekolah dan pagar, ini dilakukan secara teratur setiap dua tahun. Perawatan dilakukan dengan mengecatnya agar terlihat bersih dan rapi. Pengecatan ini biasanya dikerjakan oleh tukang. Pengecatan dimulai dari pagi hingga sore hari tanpa mengganggu kegiatan pembelajaran. Jika bagian luar pagi dicat terlebih dahulu, maka sore mengecat bagian dalam sehingga aktivitas pembelajaran tidak akan terganggu.

Meskipun demikian peme-liharaan sarana dan prasarana sekolah di MI Qurrota A'yun masih perlu ditingkatkan supaya sarana dan prasarana madrasah dalam kondisi siap untuk digunakan. Peningkatan pemeliharaan perlu dijalankan agar: a) sarana dan prasarana pendidikan tetap pada kondisi baik, masih berfungsi dan siap untuk digunakan secara optimal; b) dapat memper-panjang umur pemakaian; c) menjamin keberlangsungan aktivitas belajar; d) memastikan keamanan dan kenyamanan bagi pengguna; e) mengetahui gejala kerusakan; f) menghindari kerusakan yang mendadak; g) menghindari kerusak-an yang fatal.

\section{KESIMPULAN}

Berdasarkan hasil dari penelitian dan pembahasan manajemen sarana dan prasarana di MI Qurrota A'yun secara umum telah dilakukan dengan semestinya. Sedangkan kesimpulannya secara khusus diantaranya yaitu: Pertama, perencanaan sarana dan prasarana dijalankan oleh kepala madrasah sesuai dengan kebutuhan madrasah. Kepala madrasah mengakomodasi seluruh kebutuhan yang diusulkan. Berdasarkan usulan ini, rencana kebutuhan madrasah disiapkan pada tahun awal 
ajaran selanjutnya disesuaikan pada anggaran atau pendanaan, membuat skala keutamaan dan menentukan rancangan pengadaan. Kedua, pengadaan sarana dan prasarana dilakukan dengan membeli dan menerima sumbangan dari orang tua peserta didik. Ketiga, inventarisasi sarana dan prasarana madrasah telah dijalankan pencatatan pada buku inventaris barang. Pencataan hanya pada seluruh barang yang masuk. Keempat, penggunaan sarana dan prasarana dijalankan dengan: 1) langsung kepada pendidik sesudah dicatat dalam buku inventaris; 2) secara tidak langsung, yaitu dengan menyimpannya terlebih dahulu jika akan digunakan kemudian diambil dan sesudah digunakan disimpan kembali ke tempat asalnya. Kelima, pemeliharaan sarana dan prasarana madrasah dijalankan dengan: a) secara berkala, pemeliharaan dijalankan setiap hari, dijagaakebersihannya, digunakan pada saat dibutuhkan dan disimpan di tempatnya sesudah digunakan, memeriksa untuk memastikan kelayakannya; b) insidentil, yaitu memeriksa sarana dan prasarana setiap saat, apabila ada sesuatu yang rusak maka diperbaiki, sarana prasarana yang tidak bisa diperbaiki maka disimpan di gudang.

\section{DAFTAR PUSTAKA}

Arikunto, Suharsimi dan Lia Yuliana. (2008). Manajemen Pendidikan. Yogyakarta: Aditya Media bekerjasama dengan FIP dan UNY.

Bafadal, Ibrahim. (2003). Seri Manajemen Peningkatan Mutu Pendidikan Berbasis Sekolah Manajemen Perlengkapan Sekolah Teori dan Aplikasinya. Jakarta: PT Bumi Aksara.

Jakarta: Bumi Aksara.

Direktorat Jendral Peningkatan Mutu Pendidik dan Tenaga Kependidikan Departemen Pendidikan Nasional. (2007). Manajemen Sarana dan Prasarana Pendidikan Persekolahan Berbasis Sekolah. Jakarta: Direktorat Tenaga Kependidikan.

Mustari, Mohamad. (2015). Manajemen Pendidikan. Jakarta: Rajawali Pers.

Peraturan Menteri Pendidikan Nasional Nomor 24 Tahun 2007 tentang Standar Sarana Prasarana untuk SD/MI, SMP/MTs, dan SMA/MA.

Sugiyono. (2013). Memahami Penelitian Kualitatif. Bandung: Alfabeta. 
Syahril. (2012). Manajemen Sarana Prasarana. Padang: Jurusan Administrasi Pendidikan.

Undang-Undang Nomor 20 Tahun 2003, Tentang Sistem Pendidikan Nasional. 